\title{
Drug Prescribing Pattern (Generalized Anxiety Disorder) in Banyumas General Hospital
}

\author{
${ }^{1 s t}$ Peppy Octaviani \\ Department of Pharmacy \\ Harapan Bangsa University \\ Purwokerto, Indonesia \\ peppyoctaviani@uhb.ac.id
}

\author{
${ }^{2 n d}$ Sunarti \\ Department of Pharmacy \\ Harapan Bangsa University \\ Purwokerto, Indonesia \\ sunarti@uhb.ac.id
}

\begin{abstract}
Generalized Anxiety Disorder (GAD) is an anxiety disorder with an estimated $6 \%$ of Indonesia's population. The medication of anxiolytic must be administered appropriately according to the patient's clinical condition. This is due to the variability of individual responses to anxiolytic drugs. This study was aimed to explore the type of drug, the determinant of patient (age, gender, occupation), and duration of treatment. The study was conducted retrospectively since January $1^{\text {st }} 2017$ until December $31^{\text {st }} 2018$ at Polyclinic YANKESWA Banyumas Hospital. The sample of this study were 47 patients who meet the inclusion criteria, who received anti-anxiety drug therapy for 6-24 month, and had a complete list of clinical therapies. The results of the study showed that there were 47 medical record data of patients, with a range of age 22-63 years; and various job statuses. The therapy received by GAD patients was anxiolytic drug such as Benzodiazepines group including Alprazolam (41\%), Clobazam (9\%), and Lorazepam (11\%), SSRIs include: Fluoxetine $(6 \%)$, Sertraline $(14 \%)$ and TCA: Amitriptyline (8\%).
\end{abstract}

Keywords: GAD, prescribing pattern

\section{INTRODUCTION}

GAD is a chronic anxiety disorder characterized by persistent and excessive anxiety, and difficult to control which can be accompanied by psychological and somatic symptoms.

According to Prof. Zullies Ikawati. Ph.D (2013) anxiety disorders is associated with abnormalities in some parts of the brain and impaired function of several neurotransmitters including norepinephrine (NE), GABA (Gamma Amino Butyric Acid), and serotonin (5 -HT), amygdala structure which is a temporal lobe in the brain that plays an important role in stimulating and responding to anxiety symptoms. Locus Ceruleus (LC) located in the bone marrow is the main part of the brain that contains NE with a wider distribution area of the brain that is responsible for anxious responses (such as: vagus, hypothalamus, lateral and paraventricular). Hippocampus is an area of the brain that is responsible for both combining trauma memory stimulus and along with entorhinal cortex involving in overgeneralizing anxious responses. Hypothalamus is the main area in the overall neuroendocrine and autonomic response to anxiety improvement.

There are 3 neurochemical theories about the pathophysiology of anxiety disorders:

1. Norepinephrine (NE) model

This theory explains that people with anxiety have an excessive level of sensitivity to anxiety and an excessive reaction to stress stimulus. In response to attack stressful situations, LC acts as an alarm, activates NE, release and stimulates sympathetic and parasympathetic nerves. Anxiogenic medication (yohimbin, alpha 2 adrenergic receptor blocking agents) stimulates NE and causes noradrenergic activity.

NE can also excrete glutamate (excitatory neurotransmitters), which causes anxiety and panic disorder.

2. GABA Model

There are 2 GABA protein-receptors: GABAa and GABAb. GABA is the main inhibitory neurotransmitter in CNS that has a strong regulation or inhibitory effect on $5 \mathrm{HT}$, NE, and DOPAMIN systems. When GABA is bound to GABAa receptor, the ion channel of $\mathrm{Cl}$ opens and causes negative charge influx. This condition causes hyperpolarization of cell membranes and decreases nerve cell excitability. This decreasing effect becomes an anxiolytic mechanism of GABA against drugs, such as benzodiazepine.

3. Serotonin Model

The disorders of serotonin system which are inhibitory neurotransmitters cause disruption in the release and reuptake of presynaptic auto receptors, serotonin reuptake transporters, or the effects of serotonin on synaptic central receptors. This mechanism is believed to play a role in anxiety disorders.

Broadly speaking, anxiety can be caused by 2 factors:

1. Factors of the disease or medical disorders and medication.

a. Disease factors or medical disorders.

Some diseases related to anxiety are cardiovascular disorders (angina, arrhythmias, congestive heart failure, ischemic heart disorders and cardiac infarction), endocrine and metabolic diseases (hyperthyroidism, hyperparathyroidism, hypothyroidism, hypoglycemia, hyponatremia, hyperkalemia, pheochromocytoma, vitamin B12 deficiency and folate deficiency), neurological disorders (dementia, Parkinson, migraine, seizures, strokes, and neoplasms), respiratory disorders (asthma, COPD, pulmonary embolism and pneumonia), other diseases (anemia, SLE, and vestibular dysfunction).

b. Medication.

Some medications can also cause anxiety disorders, such as carbamazepine, antidepressants SSRI, felodipine, quinolone, antibiotic, isoniazid, theophylline, prednisone, levodopa, ibuprofen, and others. Herbal medicines such as ginseng and ephedra, and some stimulant agents that can cause anxiety (amphetamine, cocaine, caffeine), sympathomimetic 
drugs (pseudoephedrine), and thyroid hormone (levothyroxine) can also trigger anxiety. Moreover, the toxicity of some drugs can also cause anxiety (digoxin, anticholinergic and antihistamines), due to withdrawal of sedative drugs, and alcohol.

2. Factors of Mental Health Disorder

Anxiety is a clinical manifestation in a number of psychiatric disorders, a marked symptom occurs in patients with mood disorders, schizophrenia, delirium, dementia, and drug abuse.

a. This Scientific Papers was aimed to determine the pattern of drug prescription of GAD (Generalized Anxiety Disorder) at Banyumas General Hospital in 2017 - 2018 and to find out the types of GAD drugs that are widely used for GAD therapy.

b. Knowing the factors of Generalized Anxiety Disorder (GAD) patients based on age, gender and occupation of GAD patients.

c. Knowing the duration of treatment in Generalized Anxiety Disorder (GAD) patients.

\section{METHOD}

This study used a descriptive method with a quantitative approach to a population or sample. Data collection using research instruments, data analysis performed using quantitative data.

This study conducted to determine the value of an independent variable, either one variable or more (independent) without making comparisons or connecting with other variables.

Based on this theory, descriptive approach in this study is intended to get an overview of the types of GAD drugs, GAD patient determinants (age, sex, occupation) and treatment duration of GAD.

\section{RESULTS AND DISCUSSION}

\section{Types of Medication}

Based on the study in the medical records of patients, the types of drugs used in the treatment of patients with GAD in Banyumas Regional Hospital from January 2017 to December 2018 can be seen in table 1 .

TABLE 1. TYPES OF DRUGS USED IN GAD PATIENTS IN BANYUMAS REGIONAL HOSPITAL FROM JANUARY 2017 TO DECEMBER 2018

\begin{tabular}{|c|c|c|c|c|c|}
\hline \multirow{2}{*}{ No } & \multirow{2}{*}{$\begin{array}{c}\text { Class of } \\
\text { Drugs }\end{array}$} & \multicolumn{2}{|c|}{$\begin{array}{l}\text { Drugs Name } \\
\end{array}$} & \multirow{2}{*}{$\begin{array}{l}\text { Total of } \\
\text { Item }\end{array}$} & \multirow{2}{*}{ Percentage } \\
\hline & & Generic & Patent & & \\
\hline \multirow[t]{3}{*}{1} & Benzodiazepin & Alprazolam & Alganax, Zypraz & 26 & $41 \%$ \\
\hline & & Clobazam & Proclozam & 6 & $9 \%$ \\
\hline & & Lorazepam & Merlopam & 7 & $11 \%$ \\
\hline \multirow[t]{2}{*}{2} & SSRI & Fluoxetine & Kalxetin, Nopres & 6 & $9 \%$ \\
\hline & & Sertraline & Fridep & 14 & $22 \%$ \\
\hline \multirow[t]{2}{*}{3} & TCA & Amitripthyllin & & 5 & $8 \%$ \\
\hline & & Total & & 64 & $100 \%$ \\
\hline
\end{tabular}

Table 1 shows that there are 3 types of anxiolytic drugs used in the treatment of GAD patients in Banyumas Regional Hospital including Benzodiazepines which consists of Alprazolam (41\%), Clobazam (9\%), Lorazepam (11\%); SSRI class including Sertraline (22\%), Fluoxetine $(9 \%)$; and TCA class anxiety drug which is Amitriptyline (8\%).

Based on the assessment of the patient's medical record data, SSRI (Sertraline / Fluoxetine) drugs were used in the case of GAD patients who have just undergone subsequent GAD drug therapy if the patient did not respond adequately then added Benzodiazepine drugs, and in patients who have been stable it was used only Benzodiazepines (Alprazolam / lorazepam / Clobazam) medication with reference to tapper dose until the patient was completely healed. The choice of drugs type was based on the patient's responses toward the side effects of anxiety drugs, for example Clobazam was given to patients who could still recover activities due to mild sedation, while Lorazepam was given to patients with liver disorders.

The most common Benzodiazepine used is Alprazolam (41\%). It is usually prescribed in cases of GAD patients with concomitant chronic diseases (for example: in the case of cardiovascular patients, diabetes mellitus, hyperthyroid), whereas TCA class (Amitriptyline, 5\%) was not the first line-drug, but as an adjuvant to Benzodiazepine or SSRIs class.

2. Age

Based on the study results, the age of patients with GAD in Banyumas Regional Hospital from January 2017 to December 2018 with a total of 47 data patients' medical records showed in table 2 :

\begin{tabular}{|c|c|c|c|}
\hline \multicolumn{2}{|c|}{$\begin{array}{l}\text { HOSPITAL IN } \\
\text { DECEMBER } 2018 \\
\end{array}$} & HE PERIC & JANUARY \\
\hline No & Age (Years) & Number & $\begin{array}{c}\text { Percentage } \\
(\%)\end{array}$ \\
\hline 1 & $22-27$ & 2 & $4 \%$ \\
\hline 2 & $28-33$ & 7 & $15 \%$ \\
\hline 3 & $34-39$ & 11 & $23 \%$ \\
\hline 4 & $40-45$ & 3 & $6 \%$ \\
\hline 5 & $46-51$ & 15 & $32 \%$ \\
\hline 6 & $52-57$ & 4 & $9 \%$ \\
\hline 7 & $58-63$ & 5 & $11 \%$ \\
\hline & Total & 47 & $100 \%$ \\
\hline
\end{tabular}

The results showed that GAD patients in Banyumas Regional Hospital in the period January 2017 to December 2018 were dominated by adult patients aged 22-27 years as many as 2 patients (4\%), aged 28-33 years as many as 7 patients (15\%), aged $34-39$ years as many as 11 patients $(23 \%)$, age $40-45$ as many as 3 patients $(6 \%)$, age $45-51$ as many as 15 patients (32\%), age $52-57$ as many as 4 patients (9\%), and age $58-63$ years as 5 patients (11\%).

Based on observation on their medical record, it shows that the most common age of GAD patients, aged 46-51 years $(32 \%)$ are caused by disease factors or other medical disorders, according to Prof. Zullies (2013), it is stated that anxiety disorders are caused by 2 factors, including disease factors or medical disorders and medication factors. Moreover, at the age of $45-51 \%$ years, patients had the impairment of body function.

Study conducted by Rusyani (2016) suggests that factor affecting a person's anxiety disorder at the age of 45-59 years is due to the loss of the tissue ability to repair or replace itself and slowly maintain its normal function and the psychological changes that occurs (for example: phenomenon of taboo / shame on sexual aspect), and psychosocial changes (decreased cognitive and psychomotor functions, for example: the slower response to understand or react).

According to Ifdil (2017), anxiety experienced by someone between the ages of 30-39 years occurs due to many factors, for example social factors (lifestyle), 
environmental factors (having teenager children), material factors (not yet economically stable) and others.

According to the results of Suherman's study (2016), it shows that there is no significant difference between age and GAD patients, this is because GAD can be caused by various factors, for example alcoholics / drug addicts, environmental factors (family and community), post trauma factors, and others.

\section{Gender}

Data of GAD patients' gender amounting to 47 medical record data in Banyumas Regional Hospital from January 2017 to December 2018 are as follows:

TABLE 3. DATA OF GAD PATIENTS' GENDER IN BANYUMAS REGIONAL HOSPITAL FROM JANUARY 2017 TO DECEMBER 2018

\begin{tabular}{lcc}
\hline \multicolumn{1}{c}{ Gender } & Number & Percentage (\%) \\
\hline Male & 18 & $38 \%$ \\
Female & 29 & $62 \%$ \\
\hline Total & 47 & $100 \%$ \\
\hline
\end{tabular}

Based on data taken by gender shows that the number of patients with GAD in Banyumas Regional Hospital from January 2017 to December 2018 from 47 medical record data samples were 18 male patients $(38 \%)$ and 29 female patients $29(62 \%)$. From the study result, females affected by GAD was more than males because females use more emotions in dealing with problems (Fitrikasari, 2016). According to the result of Rahmawati's study (2017), women tend to have sensitive feelings so that they have higher risk of GAD than male.

Based on the observation, female gender is more affected by GAD especially at the age of 50 years due to menopause and other diseases that can cause GAD, for example: hyperthyroidism (known from the history of patient's medication). This results in excessive anxiety disorders, so it needs to treat.

Suhaidah (2013) stated that at the age of 40-50 years, women will experience menopause naturally, which causes anxiety disorders in women such as insomnia, anxiety, excessive sweating, fear, dry face, discomfort, irritability, and others, because menopausal women will experience the changes of reproductive organs (ovaries and uterus will gradually shrink, endometrium atrophy, vaginal epithelium thinning, the breast become soggy), hormonal changes (decreased ovarian function, reduced excitatory against gonadotropins), vasomotor changes (headaches, sweating, changes in blood pressure, intestinal disorders, etc.), and emotional changes (irritability, diminished morale, insomnia, etc.).

Based on study conducted by Lusiana (2014), there is a correlation between physical changes occur in menopausal women with anxiety. This is caused by increasing age in women will result the decreased of estrogen which disrupt the reproductive system in menopausal women. In addition, the decrease of estrogen causes physical changes in menopausal women such as: the skin becomes loose, the feeling of heat at night, and others.

The study of Amin, et al (2014) states that women are more often diagnosed with generalized anxiety disorders compared to men. This is based on the fact that women are more likely to admit having anxiety. Women from various backgrounds are subjects with a variety of social conditions which can predispose to a psychiatric condition mainly due to marital problems. In men, generalized anxiety disorder is diagnosed along with a history of alcohol abuse.

4. Occupation

Occupational data of patients with GAD based on the medical records at Banyumas Regional Hospital from January 2017 to December 2018 is as follows.

TABLE 4. OCCUPATIONAL DATA OF PATIENTS WITH GAD IN BANYUMAS REGIONAL HOSPITAL FROM JANUARY 2017 TO DECEMBER 2018

\begin{tabular}{ccc}
\hline Occupation & Number & Percentage (\%) \\
\hline Jobless & 12 & $26 \%$ \\
Civil servant & 13 & $28 \%$ \\
Private sector & 22 & $47 \%$ \\
\hline Total & 47 & $100 \%$ \\
\hline
\end{tabular}

From the data above, it shows that the highest percentage of GAD patients is at private sector by $47 \%$, this result shows that GAD patients who mostly undergo pharmacotherapy are patients who work in the private sector. Work environment can trigger anxiety disorders directly or indirectly, depending on how the person solves the problems and adjusts to their environment (Fitrikasari, 2016).

Based on the result of observational data, private workers are more susceptible to GAD, especially in industrial sector, and other private workers, demands for high work targets and termination of work that can occur at any time and in facing retirement (Fitrikasari, 2016).

\section{Duration of Treatment}

The time needed for the treatment of GAD patients in Banyumas Regional Hospital was investigated based on the patient's medical record data from January 2017 to December 2018 with the number of GAD patients until the patient was completely stable and off the drug was 47 .

TABLE 5. DATA OF THE TIME REQUIRED FOR GAD PATIENTS TO UNDERGO PHARMACOTHERAPY AT BANYUMAS HOSPITAL

\begin{tabular}{|c|c|c|}
\hline $\begin{array}{c}\text { Duration of } \\
\text { Treatment (Month) }\end{array}$ & Number & $\begin{array}{c}\text { Percentage } \\
(\%)\end{array}$ \\
\hline $7-9$ months & 6 & $13 \%$ \\
\hline $10-13$ months & 10 & $21 \%$ \\
\hline $14-17$ months & 13 & $28 \%$ \\
\hline $18-20$ months & 9 & $19 \%$ \\
\hline $21-24$ months & 9 & $19 \%$ \\
\hline Total & 47 & $100 \%$ \\
\hline
\end{tabular}

From the data about the time needed to treat GAD patients, duration of the treatment of 7-9 months were found in 6 patients (13\%), 10-13 months in 10 patients (21\%), 14-17 months in 13 patients (28\%), 18-20 months in 9 patients (19\%), and 21-24 months in 9 patients (19\%).

The mean of treatment duration of GAD patients in Banyumas Regional Hospital is 7.8 months, and the most stable drug off patients are in the range of 14-17 months and the least time of treatment can be stable to take off the drug is 7-9 months.

GAD patients could not stop the medication at will while pharmacotherapy is in progress. They need healing time to be completely recovered from the symptoms of GAD. The duration of treatment in GAD patients is 6 to 
24 months until the symptoms is resolved either only with pharmacotherapy or with the additional of nonpharmacotherapy (Theresia, 2016).

According to Hastuti (2012) that the time needed for the healing process of GAD patients with pharmacotherapy is 6 months to 18 months with or without the addition of CBT, ET, ACT or other therapies. However, it does not rule out the possibility that GAD patients recover before 6 months and can be even longer than 2 years due to the healing and success of treatment for GAD patients is strongly affected by family support and a conducive environment.

\section{CONCLUSION}

1. Patient factors affecting GAD: The age of most GAD sufferers is between 46-51 years, the sex most affected by GAD are women, factors of the types of work that mostly affected by GAD are private sector workers.

2. Types of drugs that are widely used for GAD therapy are Benzodiazepines including Alprazolam (41\%), Clobazam (9\%), and Lorazepam (11\%).

3. The duration of treatment of GAD patients with the shortest treatment time is 7-9 months, and the longest treatment time is $21-24$ months.

\section{ACKNOWLEDGMENT}

This study conducted based on the funding given by Harapan Bangsa University, Indonesia based on the annual research grant year 2018/2019.

\section{REFERENCES}

[1] Ali Fauzi. Mochammad.2018. Klasifikasi Penyakit Skizofrenia dan Episode Depresi pada Gangguan Kejiwaan dengan Menggunakan Metode Support Vector Machine (SVM). Jurnal Pengembangan Teknologi dan Ilmu Komputer. Volume 2(No.11): Halaman (56115618).

[2] Amin, Mahmud, dkk. 2014. Hubungan Jenis Kelamin, Status Pernikahan, dan Status Pekerjaan dengan Gangguan Ansietas Menyeluruh di Klinik Psikiatri RS dr. Pirngadi-Medan. Jurnal MKB. Volume 46 (No.4). Halaman 216-220.

[3] Anonim, 2009.Undang-Undang No.36 Tahun 2009 tantang Kesehatan.

[4] Anonim, 2014.Undang-Undang No. 18 tahun 2014 tentangKesehatanJiwa.

[5] Badan Penelitian dan Pengembangan Kesehatan. 5.Riset Kesehatan Dasar. (RISKESDAS) 2013.Jakarta: Departemen Kesehatan RI.

[6] Bandelow, B and Michaelis, S. 2015. Epidemiology of Anxiety Disolder. Journal NCBI. Volume 17 (No.3): Halaman 327-333.

[7] Bandelow, B.,Sophie, M, and Dirk, W. 2017.Treatment of Anxiety Disolder.Journal NCBI, Volume 19(No.2): Halaman 93-107

[8] Bystritsky, A.,Sahib, dkk. 2013. Current Diagnosic and Treatment of Anxiety Disolder. Journal Pharmacy and Therapeutic.Volume 38(No.1): Halaman 41-44.

[9] C. Merril. 2011. Acute Dependence on Depressant Drugs is Determined Gy Common Genes in Mice: Journal Pharmacol. Volume 3 (No.4): Halaman 112-123.
[10] Fitrikasari, Alifati. 2016. Gambaran Tingkat Kecemasan dan Hubungannya dengan Berbagai Faktor pada Pasien Rawat Jalan di PUSKESMAS Halmahera Semarang. Jurnal Kedokteran Diponegoro, Volume 5 (No.4): Halaman 1451-1460.

[11] Hastuti Widyo Lita, dkk, 2012.PenerapanCognitive-Behavioural Therapy untuk Menurunkan GAD Pada Remaja. Jurnal Proyeksi. Volume 12 (No.1): Halaman 77-87

[12] Ifdil, B Khairul. 2016. Konsep Kecemasan (Anxiety) pada Lanjut Usia (Lansia).Jurnal ISSN, Volume 14(No. 4): Halaman 176-181.

[13] Ikawati,Zullies.2013.Farmakoterapi Penyakit Sistem Syaraf Pusat, jilid 2. Jakarta: Bursa Buku. Halaman283-314.

[14] JR, Strawn., dkk. 2018. Buspirone in Children and Adolecent with Anxiety : A Review and Bayesian Analysis of Abandoned Randomized Contrlled Trials. Journal Pharmacol, Volume 28(No.1): Halaman 2-9.

[15] Kaunang, Theresia. 2016. Gambaran Tingkat Kecemasan yang Mengalami Kekerasan di SD Kecamatan Malalayang Kota Manado. Jurnal e-Clinic. Volume 4 (No. 2): Halaman 78-102.

[16] Lamba, T., dkk. 2017. Gambaran Tingkat Kecemasan pada Warga yang Tinggal di Daerah Rawan Banjir Khususnya Warga di Kelurahan Tikala Ares kota Manado. Jurnal e-Clinic. Volume 5 (No.2): Halaman 64-73.

[17] Locke, B, L., Nell, K., and Cameron. 2015. Diagnosic and Management of Generalized Anxiety Disolder in Adult. Journal American Family Physician, Volume 91(N0.9): Halaman 205-209.

[18] Lusiana, Novita. 2014. Faktor-faktor yang berhubungan dengan kecemasan wanita dalam menghadapi menopause di Puskesmas Melur-Pekanbaru. Jurnal Kesehatan. Volume VIII (No.1): halaman 108-113.

[19] Muslimin, Khaerul. 2013. Faktor-Faktor yang Mempengaruhi Kecemasan Berkomunikasi di Depan Umum. Jurnal Interaksi. Volume II(No.2): Halaman 42-52.

[20] Nurwita, Catur. 2016. Epilepsi dan Budaya.Jurnal ISSN (UGM). Volume 24 (No.1): Halaman 22-31.

[21] Notoatmodjo, S. 2012. Metodologi Penelitian Kesehatan. Jakarta: Rineka Cipta.

[22] Rahayu, Septirina. 2016. Pencegahan Gangguan Kecemasan dengan Intervensi Berbasis WEB.Jurnal ISSN. Volume 3(No.1): Halaman 5669.

[23] Rahmawati, Asri. 2017.Faktor-Faktor yang Berhubungan dengan Tingkat Kecemasan pada Pasien Preoperative di RS Mitra Husada Pringsewu. Jurnal Kesehatan. Volume VIII(No.1): Halaman 108-113.

[24] Rickels K and Moeller HJ. 2018. Benzodiazepines in Anxiety Disolder : Reassessment of Usefullness and Safety.Journal American. Volume 4 (No.2): Halaman 117-125.

[25] Yeni, Rusyani. (2016). Faktor-faktor yang mempengaruhi kecemasan pada usia pertengahan dalam menghadapi proses menua (aging process) di Kelurahan Jogosetran Kecamatan Kalikotes Klaten. Skripsi. Sekolah Tinggi Ilmu Kesehatan (STIKES) Duta Gama Klaten. Klaten. 56-59.

[26] Sinuraya, Kurnia, Rano., dkk. 2018. Review : Farmakoterapi Gangguan Anxietas.Jurnal Suplemen. Volume 16(No.1): Halaman 212-216.

[27] Sugiyono. 2016. Metode Penelitian Kuantitatif, Kualitatif, dan R \& D. Bandung: Alfabeta.

[28] Syamsu, Yusuf. 2009.Terapi Psikospirtual untuk Hidup Sehat Berkualitas. Bandung: Maetro.

[29] Yusniyati.Asih. 2014.Pengaruh Relaksasi Otot Progresif terhadap Penurunan Tingkat Kecemasan pada Pasien pre Operasi. Jurnal Keperawatan ISSN, Volume 2 (No.3): Halaman 38-66. 